\title{
Histo-Chromatographic Finger Printing Profiles of the Root of Plumbago zeylanica Linn and Quantification of Marker Compound, Plumbagin
}

\author{
Madathilparambil Vasu Sudhakaran
}

\author{
Madathilparambil Vasu \\ Sudhakaran \\ UGC Academic Staff College, University \\ of Calicut, Calicut University PO, \\ Malappuram -673635, Kerala, INDIA \\ Correspondence \\ Dr. Sudhakaran, M.V \\ UGC Academic Staff College, University \\ of Calicut, Calicut University PO, \\ Malappuram -673635, Kerala, INDIA. \\ Phone no: 91- 471-2555125 (R): \\ Mob. 9447500125 \\ E-mail: dr.sudhakaranvasu@gmail.com \& \\ dr.sudhakaranvasu@yahoo.co.in

\section{History} \\ - Submission Date: 24-08-2017; \\ - Review completed: 11-09-2017; \\ - Accepted Date: 02-11-2017
}

DOI : 10.5530/pj.2017.6s.161

Article Available online

http://www.phcogj.com/v9/i6s

\section{Copyright}

(C) 2017 Phcog.Net. This is an openaccess article distributed under the terms of the Creative Commons Attribution 4.0 International license.

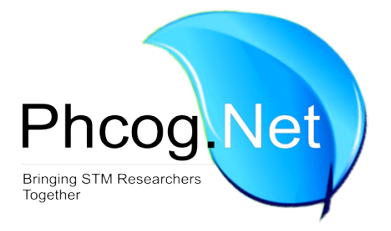

\begin{abstract}
Background: Plumbagin, a plant-derived naphthoquinone is known to be biosynthesized by polyacetate-malonate pathway. The ayurvedic drug Chitraka is obtained from the medicinal plant Plumbago zeylanica Linn, which belongs to the family Plumbaginaceae. The Chitraka is found used in the traditional forms of medicine for the treatment of various illnesses, since ancient times. Aim: The present study concerns the microscopic, powder and quantitative microscopic characteristics of the root of Plumbago zeylanica Linn. Materials and Methods: Delimiting the morpho-histological profile of the root using digital, stereo and polarized microscopic techniques and to develop the chromatogram of the extract of the root of Plumbago zeylanica Linn using High performance thin-layer chromatographic (HPTLC) method. Results: The presence of cortical deposition of plumbagin pigment as yellowish tints in the surface view of the sections of root, arrangement of starch grains as bunches of grapes in cortical tissues and ray parenchyma, crystal idioblasts containing calcium oxalate embedded in the intervening walls of the cortical cells, distinct band or patch of sclreids at the pericyclic region of the phloem, wood with non-storied cambium, distinct growth ring boundaries, paratracheal axial parenchyma, chains of vessels in radial multiplies of three to four, uniseriate to biseriate medullary rays with homogeneous cells, crowding of vessels at the central portion of secondary xylem, wood plugged with tylosis and low mesomorphy ratio for wood were the anatomical features characteristics of the taxon. The HPTLC profile of the methanol extract of root developed using the mobile phase, $n$-hexane:ethyl acetate $(8: 2 \mathrm{v} / \mathrm{v})$ had revealed four phytoconstituents. The $R_{f}$ value for plumbagin $\left(\mathrm{C}_{11} \mathrm{H}_{8} \mathrm{O}_{3}\right)$ was found to be 0.86 . Densitometric scanning had shown $\lambda_{\max }$ of plumbagin at $270 \mathrm{~nm}$. Spectral matching by overlaying the spectra of both standards and extract of root sample were confirmed the specificity of $\lambda_{\max }$ at $270 \mathrm{~nm}$ for the marker compound. The calibration curve was found to be linear in the concentration range of 2.00 to $10.00 \mu \mathrm{g} /$ band with the polynomial calibration equation $Y=178.8+91.61 * X+-4.825^{*} X^{2}$ and estimated that $5 \mu \mathrm{L}$ of methanol extract of roots contained $1.326 \mu \mathrm{g}$ of plumbagin. Thus the content of marker constituent (plumbagin) present in shade-dried roots of Plumbago zeylanica Linn (a Kerala habitant) was estimated as $0.179 \%$. Conclusion: The present study suggests that the delineated characteristics of the roots of Plumbago zeylanica Linn could tag as the identifying parameters to substantiate and authenticate the raw drugs from the spurious/adulterants materials and developed HPTLC method could be effectively used for the regulatory perspectives and quality assessment of plumbagin in the polyherbal formulation/finished products of traditional medicine.

Key words: Axial Parenchyma, Mesomorphy Ratio, Tylosis, Plumbagin, Calibration Curve.
\end{abstract}

\section{INTRODUCTION}

Plumbagin, a plant-derived naphthoquinone (IUPAC: 5-hyroxy-2-methyl 1,4 naphthoquinone or 5-hydroxyl2-methyl-naphthalene-1,4-dione) pigment is obtained from a few taxonomically related families of the order Charyophyllales, which include Droseraceae (eg., Aldrovanda, Drosera, Dionaea) Plumbaginaceae (eg., Ceretostigma, Plumbago), Ancistrocladaceae (eg., Ancistrocladus), Dioncophyllaceae (eg., Dionocophyllum, Triphyophyllum), Nepenthaceae (eg., Nepenthus) and also from the genus Diospyros, an unrelated Ebenaceae family. ${ }^{1}$ Members of these families are in common

having the production of bioactive 1,4 naphthoquinones $(1,4-\mathrm{NQs})$, a group of highly reactive small molecules scaffolding several potential pharmacological and therapeutic actions. The plant-derived 1,4-NQs are known to be biosynthesized from several metabolic pathways, and their 1,4-naphthalenoid ring often bearing one or more methyl, hydroxyl and/or methoxy substitutions in diverse species. Plumbagin was first isolated in 1828 from the plumbago species, in a fairly pure condition by Dulong $^{2}$ and it was named so, after the genus from

Cite this article: Sudhakaran M.V. Histo-Chromatographic Finger Printing Profiles of the Root of Plumbago zeylanica Linn and Quantification of Marker Compound, Plumbagin. Pharmacog J. 2017;9(6)Suppl:s77-s86. 
which it isolated. The empirical formula of plumbagin $\left(\mathrm{C}_{11} \mathrm{H}_{8} \mathrm{O}_{3}\right)$ was established in 1934 by A. Madinaveitia and Gallego. Plumbagin is known to be biosynthesized by polyacetate-malonate pathway. ${ }^{3,4}$ It is synthesized from two carbon units derived from activated acetates in the form of acetyl CoA and malonyl CoA and form six acetates units, one carbon is lost. Subsequent cyclization and aromatization of the poly acetate chain yielding eleven carbon skeleton with two six membered ring, a benzene moiety fused with cyclic diketone (Figure 1).

Plumbagin is the major active principle of Plumbago species. It is a powerful irritant and toxin. The toxic effects are associated with its interaction as pro-oxidant; it can transfer electrons from a biological substrate to oxygen, causing the cellular production of ROS (reactive oxygen species) by reducing oxygen. Plumbagin can also react as electrondeficient electrophile, forming covalent bonds with nucleophilic functional groups of cellular metabolites, causing alteration in gene expression. ROS molecules like superoxide, hydroxyl radical, and hydrogen peroxide cause oxidative damage to protein, DNA and phospholipids. ${ }^{5,6}$ Thus having the properties of being a reactive oxygen species (ROS) generator and apoptosis inducing agent, plumbagin has recently been implicated with altering multiple cancer -signaling pathways and reported to have shown immense potentials in anticancer (such as breast, prostrate, ovarian, lung, liver, pancreatic, renal, cervical and skin cancer, also in myeloma and leukemia $)^{7-14}$ therapy and in radiation therapy as the chemosensitizer and radiosensitizer. ${ }^{15-17}$

Genus Plumbago(Plum-Bay-go)of the family Plumbaginaceae is comprised of about 17 species. ${ }^{18}$ They are found distributed mostly in semi-arid regions of Medititerranan and Central Asia and grow in salty, calcareous, rocky and other dry habitat. Three species of Plumbago are found distributed in India. They are P. zeylanica Linn, P.indica Linn and P.capensis Thunb. The root is the official part from which the drug Chitraka is obtained. Plumbago zeylanica Linn and P.indica Linn are espoused as source for the drug, Chitraka. Of these white plumbago (Plumbago zeylanica Linn.) is being used by the physician of Northern India. Whereas, in Sourthern States including Kerala preferred, the red flowered plumbago (P.indica Linn.) as the source plant for Chitraka. ${ }^{19}$ Since ancient times, the root and whole plant of Plumbago zeylanica were found used in several traditional systems of medicine including Ayurveda, Chinese, sub-Saharan, Kempo, for the treatment of rheumatic pain, diarrhea, dyspepsia, pustule, skin diseases and as a diaphoretic, appetite stimulant, vesicant and contraceptive agent. ${ }^{19,20,21}$ The pulp of the whole plant or roots of $P$. zeylanica have found used in folklore as abortifacient agent by inserting it into the female genitalia. Chitraka is one of the major ingredients in many Ayurvedic formulation including Citrakasavam, Dasamularistam, Gulguluktakam kasayam, and Yogarajachurnam. ${ }^{19}$

Since it is an important traditional remedy for several ailments, P. zeylanica Linn have extensively been investigated by various workers for the phytochemical, ${ }^{22,23}$ microbiological, ${ }^{24,25}$ in vitro microprogation, ${ }^{26}$ pharmacological $^{27}$ and physiological studies ${ }^{28}$ Many recent experimental studies have shown that plant having multiple therapeutic potentials including antioxidant, anti-inflammatory, anti-leishmanial, antifeedent, antibacterial, antifungal, antiatherogenic activities and also have cardiotonic, hepatoprotective, neuroprotective and central nervous system stimulating effects. ${ }^{29,30}$ However, the botanical standards specified for appraisal of officinal part (ie, root) of $P$. zeylanica seemed to be too scanty in literature (1-33 $^{31}$ and the available literatures are not exhaustive enough to extricate the crude raw material from the adulterants and substitutes. Therefore, the present study was undertaken with the objectives of elaborating the morphological and histological characteristics of the root of P. zeylanica using the techniques of digital, polarizing and stereo microscopy. It also aims to delineate and establish pharmacongostic markers and chromatographic finger print of the root extract of $P$. zeylanica, which could serve some of the important target regarding the regulatory aspects of quality control measures and as a rapid method for, quantify the marker compound plumbagin in the traditional herbal formulation/ finished product.

\section{MATERIALS AND METHOD}

\section{Materials}

The plant is a perennial spreading shrub, often grows in salty, dry places or coastal habitat. Stem is greenish, cylindrical, striated, slender and weak. Sprawling stem with profuse branches often appeared intertwined and branches attain a height up to 1- $1.5 \mathrm{~m}$ (Figure 2). Leaf are simple, membranous, alternate, lamina is broadly cordate at the base, acuminate at apex with entire margin. Leaves contained the calcium salt or chalk secreting glands. Flowers are pentamerous, occur in cluster in spike like racemes at the tip of branches. Flowers are white in color, calyx is persistent, tubular with five lobes and sticky, covered by many mucilage secreting emergences on their surfaces. Fruit is linear acheme. Seed is capsule; small in size contains hairs on their surfaces, which stick to the fur of animals' and aid in long distance distribution.

\section{Methods}

\section{Delineation of Microscopic markers}

Plumbago zeylanica Linn. for the present study was collected from the natural habitat of Thiruvananthapuram District of State of Kerala and identification and authentication were done using Gamble's Flora of Presidency of Madras. Fine hand sections of transverse longitudinal and radial planes of the roots were taken using the standard procedures. Sections were stained with aqueous Safranin $1 \%$ and mounted in glycerin. The investigation on macroscopic, micromorpho diagnostic profile, and powder microscopic properties of the specimens were undertaken. Microphotographs of sections and powder analysis were made by using Olympus Microscope (Model CX 41; Tokyo, Japan) with CCD camera 2 mega pixel and quantitative measurements were taken using Olympus Image-Pro Plus, version 5.1 software. The descriptive terms of the anatomical features used here as per Metcalfe and Chalk ${ }^{34}$ and Sudhakaran. ${ }^{35}$ The mesomorphy values ratio for wood was estimated based on Carlquist \& Boggs method. ${ }^{36}$ The shade-dried roots were pulverized and passed through an 85-mesh sieve. The root powder was cleared with absolute alcohol and mounted on glass slides for powder analysis. The pulverized powder was kept in a labeled, air tight glass container for chromatographic analysis.

\section{Development of Chromatogram by High-Performance Thin-Layer Chromatography (HPTLC) Chemicals and reagents}

Aluminum plate $(20 \times 10 \mathrm{~cm})$ pre-coated with silica gel 60 F254 (Merck) of uniform thickness was used as adsorbent. Analytically pure standard Plumbagin procured from Sigma and solvents of HPLC/ Chromatographic Grade procured from Merck and Qualigens Fine Chemicals, India were used.

\section{Optimization of Chromatographic Conditions}

The chromatographic separation was achieved, using different ratios of solvents of varying polarity and the mobile phase consisted of $\mathrm{n}$-hexane:ethyl acetate $(8: 2 \mathrm{v} / \mathrm{v})$ was found suitable for resolved separation of the analytes and quantification of marker compound. 


\section{Standard stock solution}

The standard stock solution $10.5 \mathrm{mg} / \mathrm{mL}$ of plumbagin was prepared in HPTLC-grade methanol. One $\mathrm{ml}$ of this stock solution was diluted with $10 \mathrm{ml}$ of methanol and a working solution of $1.05 \mathrm{mg} / \mathrm{mL}$ concentration was prepared and used for the HPTLC analysis.

\section{Sample preparation}

Accurately weighed 1.5 gms of root powder of P. zeylanica Linn was refluxed in $25 \mathrm{ml}$ of Methanol. Extract obtained was filtered using Whatman filter paper and transferred to a volumetric flask, and volume was made upto $10 \mathrm{ml}$ with methanol.

\section{Instrumentation}

CAMAG HPTLC System (Switzerland) equipped with CAMAG Linomat V Automatic Sample Spotter with syringe (100 $\mu \mathrm{l})$, Twin trough glass chamber, UV cabinet with dual wavelength, and the densitometer consisted of TLC scanner 3 linked to WINCATS software were used.

\section{HPTLC Methods}

For the HPTLC analyses, five different application volumes of the working solution were used in five different tracks on the pre-coated plate of Silica Gel and methanol root extract of the test sample in one track (track no.3). The spotting volume of standard working solution were $1,3,5,7$ and $9 \mu \mathrm{l}$ with concentrations ranged from 1.05 to $9.45 \mu \mathrm{l} / \mathrm{band}$ respectively and the volume of root extract on the plate was $5 \mu$ (ie., five standards plus one methanol extract of the root sample). The plate $(20 \times 10 \mathrm{~cm})$ was developed in Twin trough glass chamber, saturated with the mobile phase n-hexane: ethyl acetate $(8: 2 \mathrm{v} / \mathrm{v})$. Densitometric scanning of the plate at $254 \mathrm{~nm}$ and $270 \mathrm{~nm}$ were performed using CAMAG TLC Scanner 3, and operated by the WINCATS software. Calibration graph was plotted using the peak height vs concentration of the standard marker compound. The content of plumbagin present in the methanol extract of the root was estimated using polynomial regression equation. The developed HPTLC method was validated for the parameters like specificity, linearity, limit of detection (LOD) and limit of quantitation (LOQ).

\section{RESULTS AND DISCUSSION}

\section{Microscopic Evaluation of Root}

Root is elongated cylindrical shaped, straight or slightly twisted and curved at places. Bark appeared brownish- yellow in color and surface appeared smooth (Figure 3). When cut, the root appeared starchy white internally. Transverse section (T.S) of the root showed somewhat circular outline with external bordering cork cells were interrupted at places and margin appeared irregular (Figure $4 \& 4 c$ ). The tissue organization of the root consisted of an outer narrow zone of cork, followed by middle cortex and inner most zone of wood. Of these, wood was the comparatively larger area comprised of about $60 \%$ of the volume, followed by cortex (about 30\%).Conspicuous cork was composed of 6-7 layers (Figure 4a \& $\mathbf{4 b}$ ) of regularly arranged rectangular cells. The outer 2-3 layers of cork were compactly arranged, thick walled, cells were square or rectangular in shape and filled with blackish brown contents, followed by inner 3-4 layers of cells which often filled with colored substances. Phellogen was distinct and consisted of one to two rows of cells. Cortex formed a narrow zone, which consisted of 14-16 layers of cells. The outer cortex contained 5-6 layers of elongated thick-walled, large parenchymatous ells. Cells were polygonal in shape filled with reddish brown content. Inner cortex consisted of 7-9 layers, composed of relatively small cells, square or rectangular in shape. The intervening walls between the cortical cells often embedded with crystal idioblasts, which contained prismatic crystals of calcium oxalate. The crystals varied in size, and ranged from

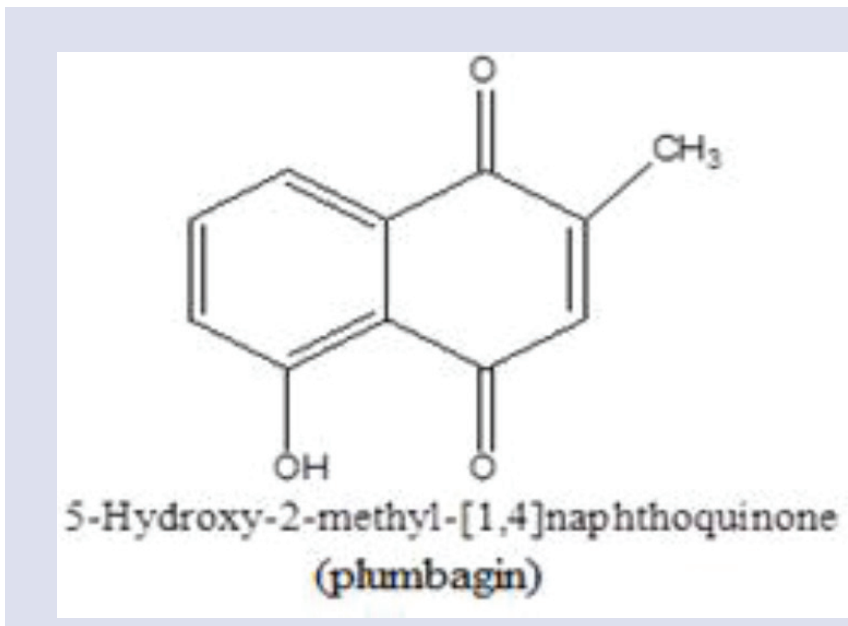

Figure 1: Structure of plumbagin

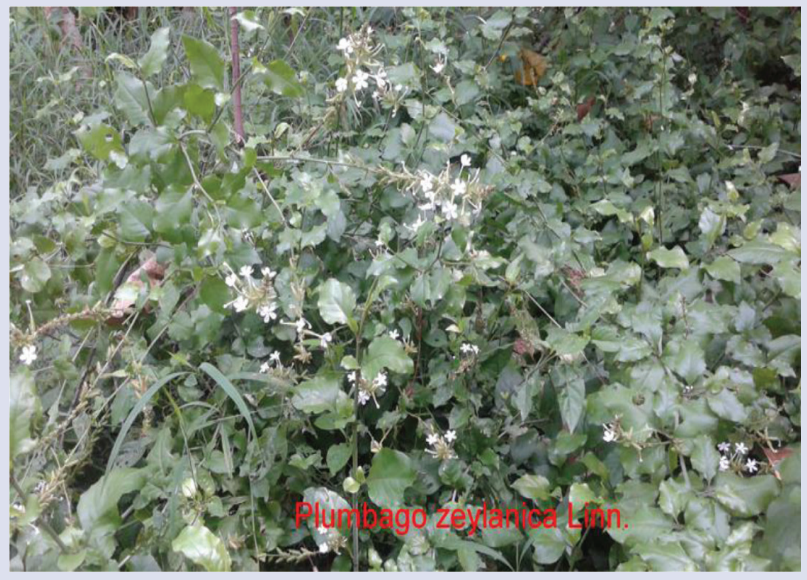

Figure 2: Plumbago zeylanica Linn.

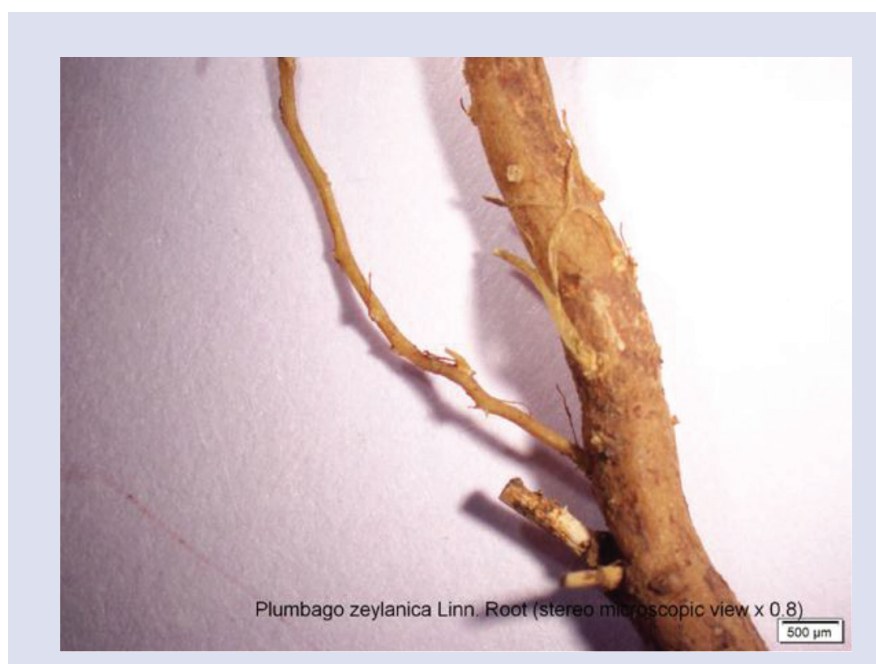

Figure 3: Plumbago zeylanica Linn. Root (stereo microscopic view $x 0.8)$ 


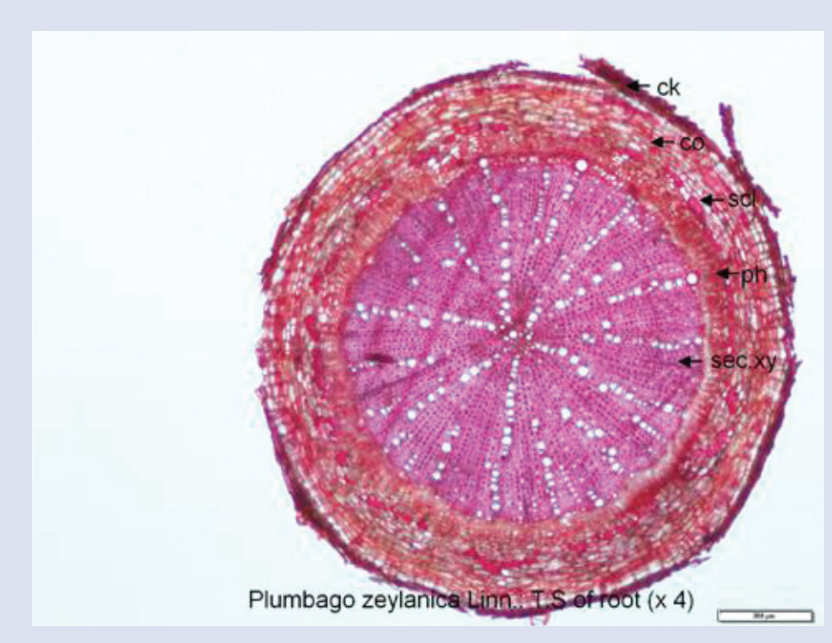

Figure 4: Plumbago zeylanica Linn. T.S of root $(x 4)$

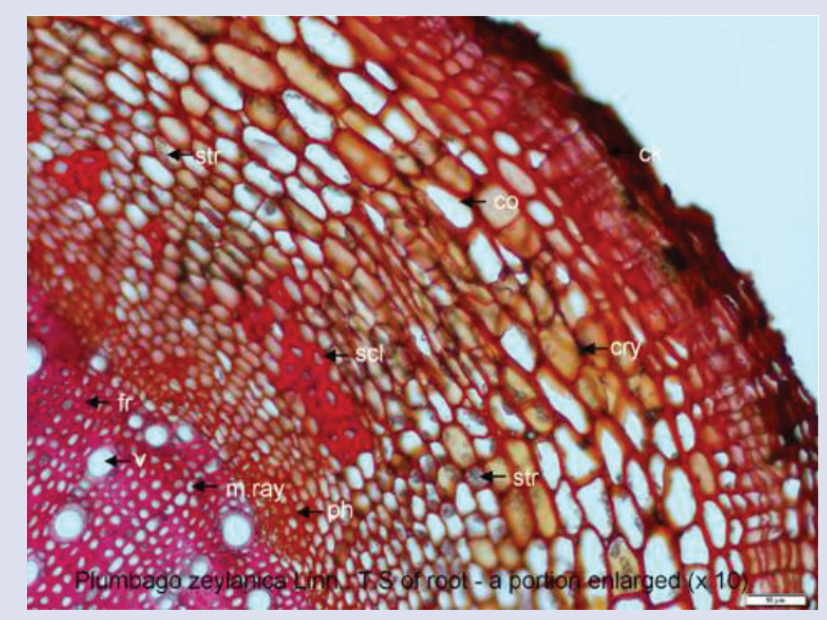

Figure 4a: Plumbago zeylanica Linn. T.S of root: a portion enlarged (x 10)

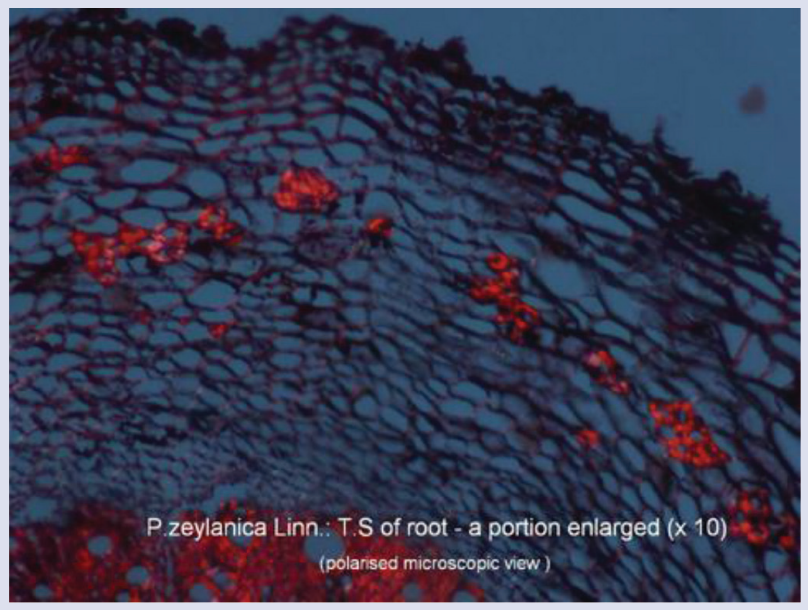

Figure 4b: Plumbago zeylanica Linn. T.S of root: a portion enlarged (x 10)

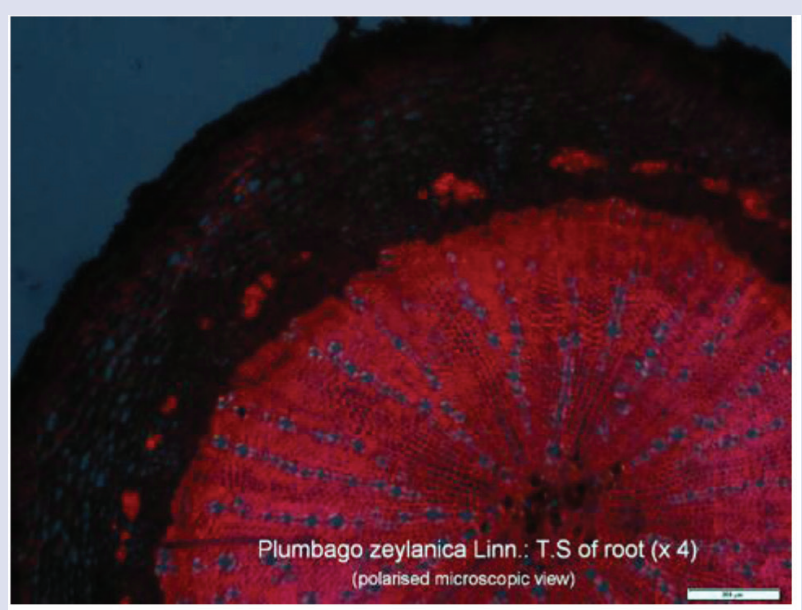

Figure 4c: Plumbago zeylanica Linn. T.S of root: (polarized microscopic view $\times 4$ )

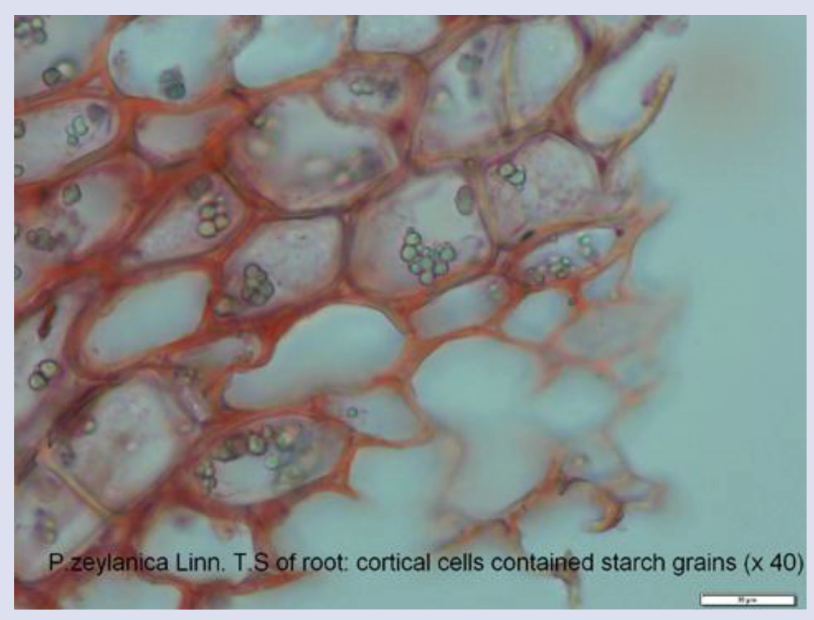

Figure 4d: P. zeylanica Linn. T.S of root: cortical cells contained starch grains $(x 40)$

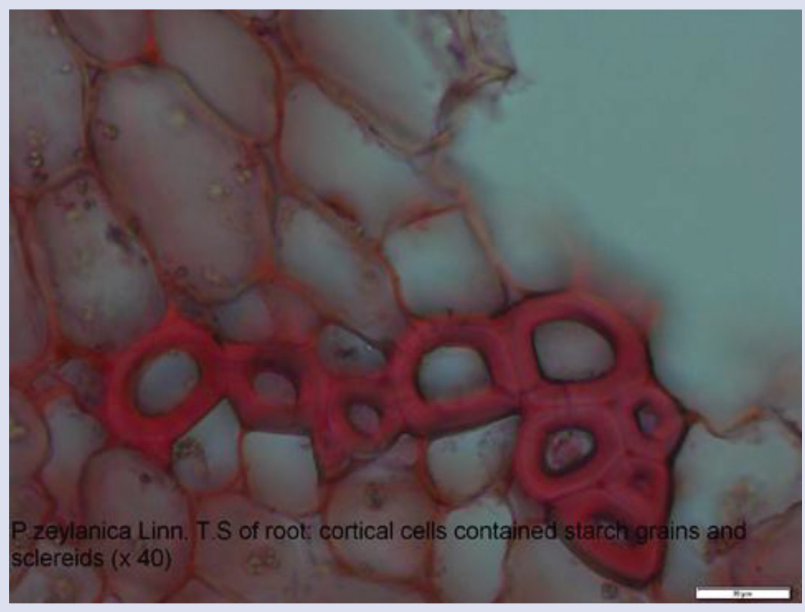

Figure 4e: P.zeylanica Linn. T.S of root: cortical cells with starch grains \& sclereids ( $x$ 40) 


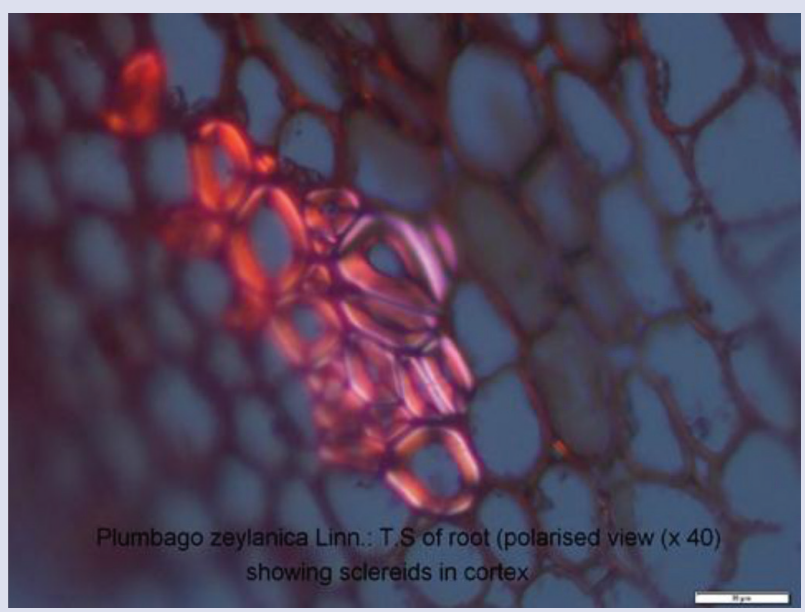

Figure 4f: P. zeylanica Linn. T.S of root: showing sclereids in cortex (polarized view $\times 40$ )

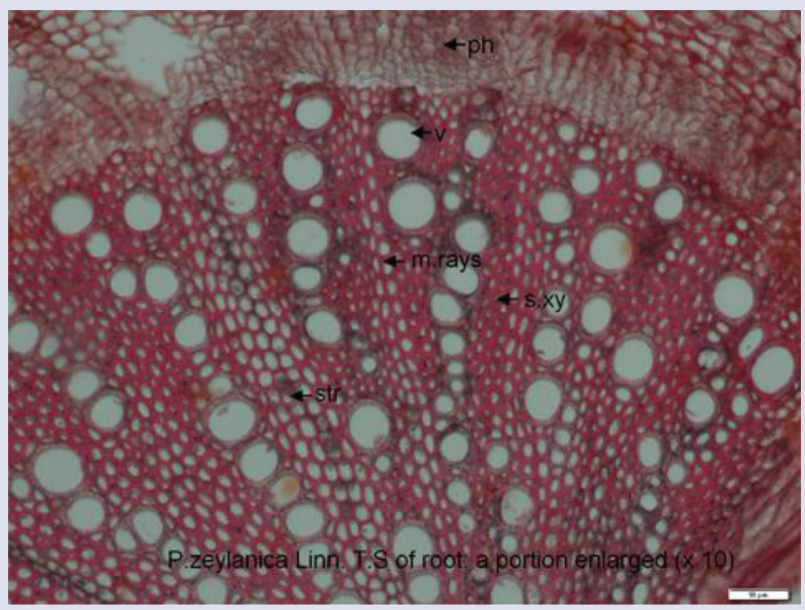

Figure 4g: P. zeylanica Linn. T.S of root: a portion enlarged (x 10)

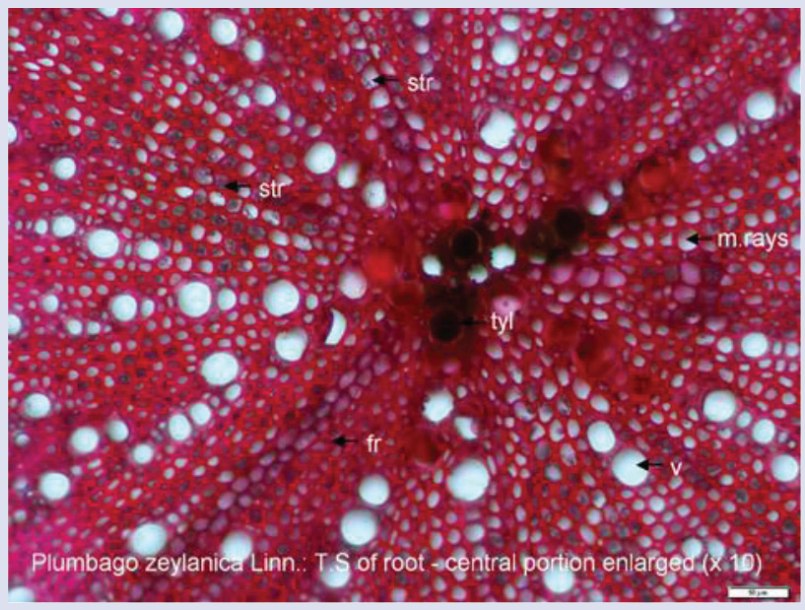

Figure 4h: P.zeylanica Linn. T.S of root: central portion enlarged (x 10)

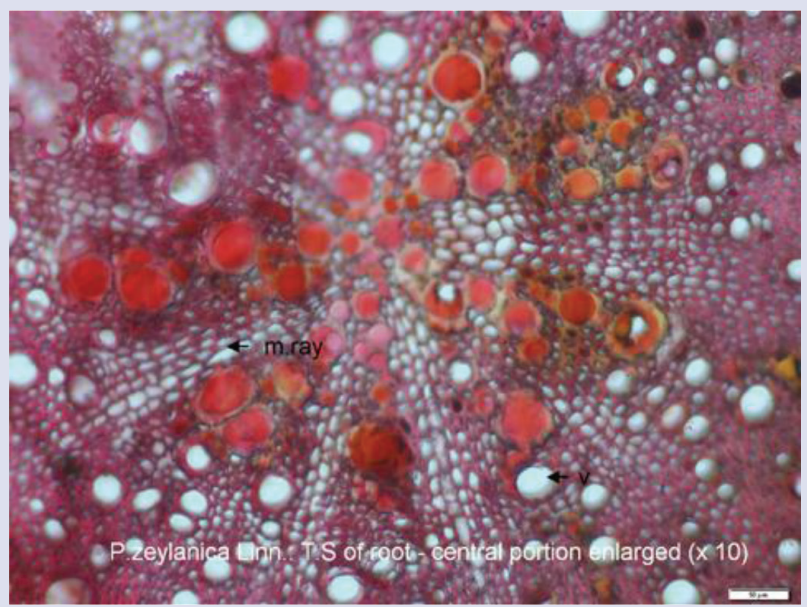

Figure 4i: P. zeylanica Linn. T.S of root: central portion enlarged (x 10)

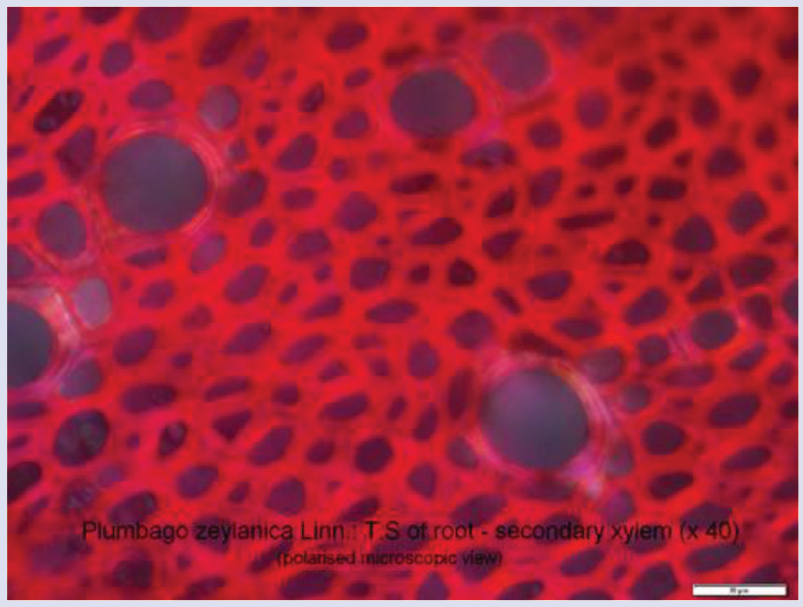

Figure 4j: P. zeylanica Linn. T.S of root: secondary xylem (polarized view $x$ 40)

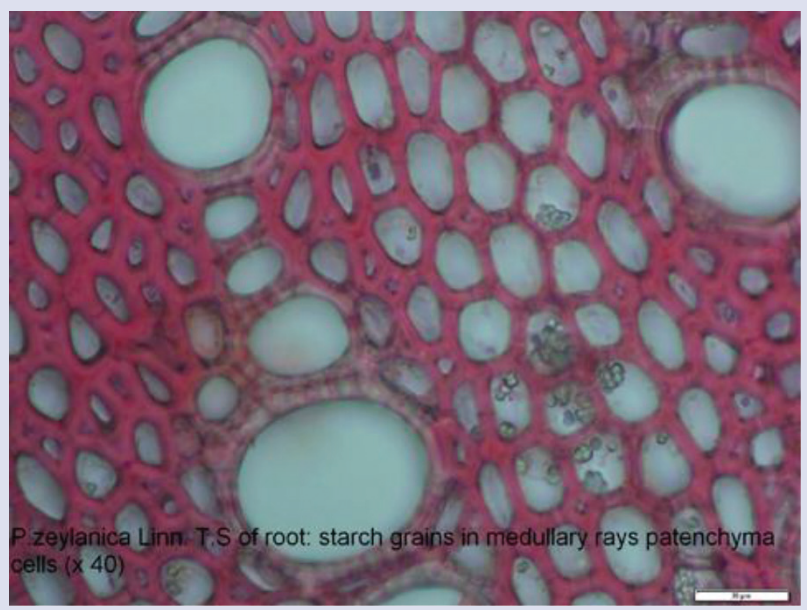

Figure 4k: P. zeylanica Linn. T.S of root: starch grains in medullary ray cells $(x 40)$ 
$20 \mu \mathrm{m}$ to $34 \mu \mathrm{m}$ in length and 10 to $13 \mu \mathrm{m}$ in diameter. The cortical cells also contained abundant deposition of starch grains. Starch grains were of both simple and compound types; however, the latter became the predominant type and seemed to be arranged in the form of bunches of grapes (Figure 4d). Starch grain was oval to elliptical in shape, and individual grain ranged in size from $4.5 \mu \mathrm{m}$ to $8.1 \mu \mathrm{m}$ in diameter. The cut surface of the root specimens, when exposed to air and viewed under the microscope plumbagin pigment was found to be oozed out from the cortical tissues, which could be very discernible in microphotograph as yellowish tints (Figure 5). Solitary sclereid or three to four rows of sclereids (Figure $4 \mathrm{f} \& 4 \mathrm{~g}$ ) were found aligned as distinct band or patch at the pericyclic region of the phloem. Several such small patches of sclereids were found distributed throughout, so as to form a more or less continuous ring across the inner cortical tissues of root, leaving a broad area of parenchyma between the bands of sclerids. The secondary walls of sclereids were heavily lignified with wide lumen. The lignified sclereids of the cortex could be distinctively discernible (Figure 4e \& 4f) under polarized light and appeared birefringent (Figure $4 \mathrm{~g}$ ), because their wall constituents of microfibrils contain crystalline cellulose, which could appear as bright in microphotographs (Figure $4 \mathrm{~g}$ ). Wood occupied the major portion of the root; growth ring boundaries were distinct on the secondary xylem. The bulk of the wood was constituted by libriform fibers (Figure $4 \mathrm{~d}$ ) and vessels distributed in radial rows (Figure $4 \mathrm{~h} \& 4 \mathrm{j}$ ). The secondary wall of libriform fibers appeared thin to thick walled leaving prominent lumens in the center, which were conspicuously wide opened (Figure 4j). Wood was formed from non-storied cambium (Figure 5a \& 5b), lacking the longitudinal series of cell arrangements of rays, axial parenchyma or libriform fibres on tangential surface (Figure 5b). Distribution of axial parenchyma in wood appeared to be of paratracheal (Figure 4j). Medullary rays were very conspicuous and the abundance of ray parenchyma cells between xylem strands was discernible in cross section. Medullary rays were of uniseriate and biseriate (Figure 5b) types and rays lacking vessel contacts. Medullary rays were homogeneous, consisted of mostly upright cells (Figure 5b). At places the accumulation of starch grains was found in medullary ray parenchyma cells (Figure 4k). Vessels were mostly occurred in radial chains, vessels grouping of radial multiple of three to six (Figure 4k) were common. Solitary vessel was found to be ovoid or polygonal in shape (Figure $4 \mathrm{i} \& 4 \mathrm{j}$ ). The diameter of the vessels was found to be small, which ranged between $24.4 \mu \mathrm{m}$ to $50.6 \mu \mathrm{m}$ with a mean diameter of about $34 \mu \mathrm{m}$. The length of the xylem elements was ranged between $127.4 \mu \mathrm{m}$ to $132.6 \mu \mathrm{m}$ with a mean length of about $130 \mu \mathrm{m}$. When the Xylem was scanned for vessel density measurement, the mean vessel density was found to be 301 per $\mathrm{mm}^{2}$ and mesomorphy ratio for P.zeylanica averaged was found to be 9.8. Mesomorphy ratio values obtained for P.zeylanica was notably low compared to woods growing in most moist regions. ${ }^{37}$ However, the value obtained in the present study is found to be in agreement with mesomorphy ratio values for Plumbaginaceae family in general ${ }^{37}$ with the concept that Plumbaginaceae plants characteristically grow in dry and or saline habitat. At the center portion of secondary xylem showed somewhat a crowding of vessels and most vessels at the center of the wood seemed to be plugged with tylosis. The presence of tylosis in the vessels (Figure 4i \& 4j) and the latter contained the deposition of secretary substances were common features of the wood of $P$. zeylanica. Radial longitudinal section (RLS) of the root had shown that vessels having bordered pits with prominent margo and outer part of the secondary wall shaved by sectioning had shown the grooves interconnecting pit apertures (Figure 5c). Intervessel pitting or vessel to vessel pitting was found to be multiseriate and in alternate (Figure 5c) position. Pits were moderately sparse and the diameter of the pit aperture was found to be about $6.3 \mu \mathrm{m}$ (Figure $5 \mathrm{c}$ ).

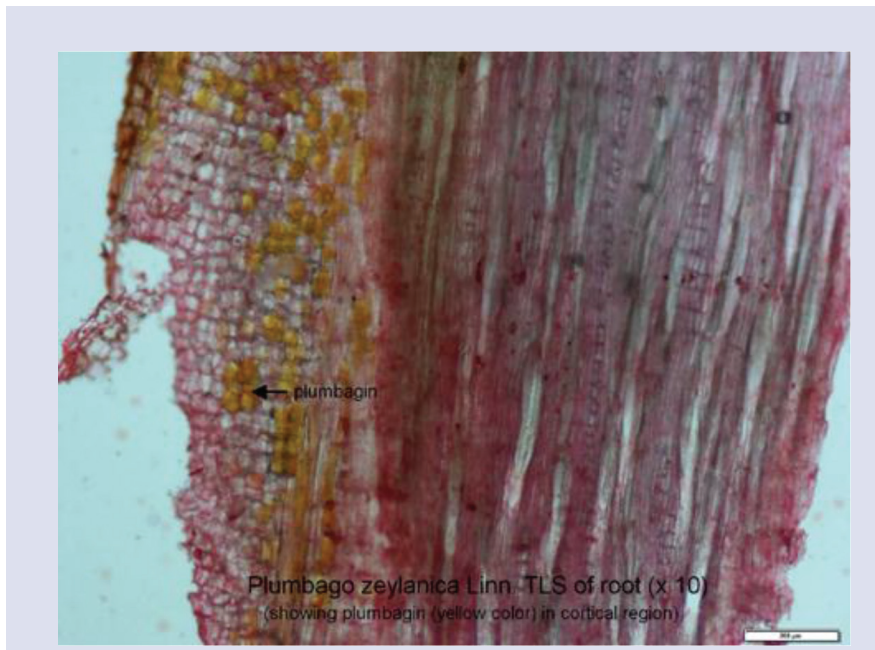

Figure 5: P. zeylanica Linn. TLS of root: deposition of plumbagin (yellow color) in cortex (x 10)

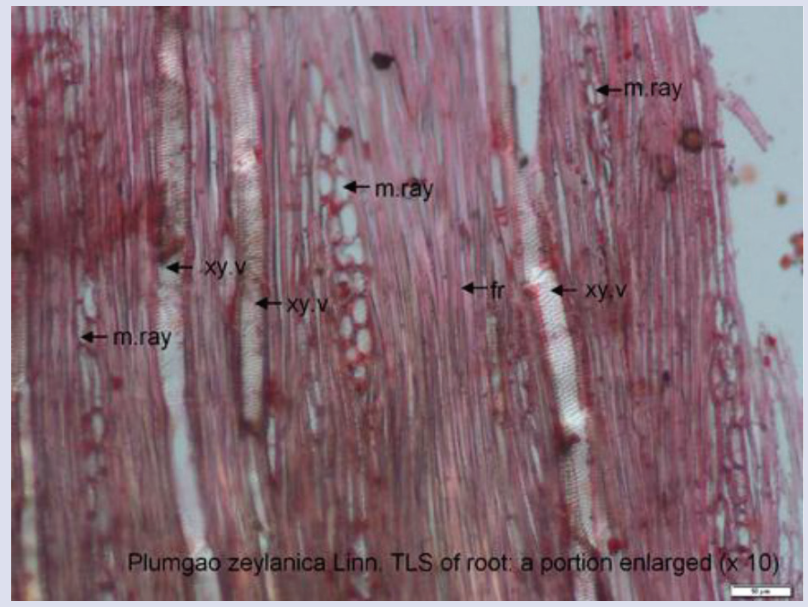

Figure 5a: P. zeylanica Linn. TLS of root: a portion enlarged ( $x$ 10)

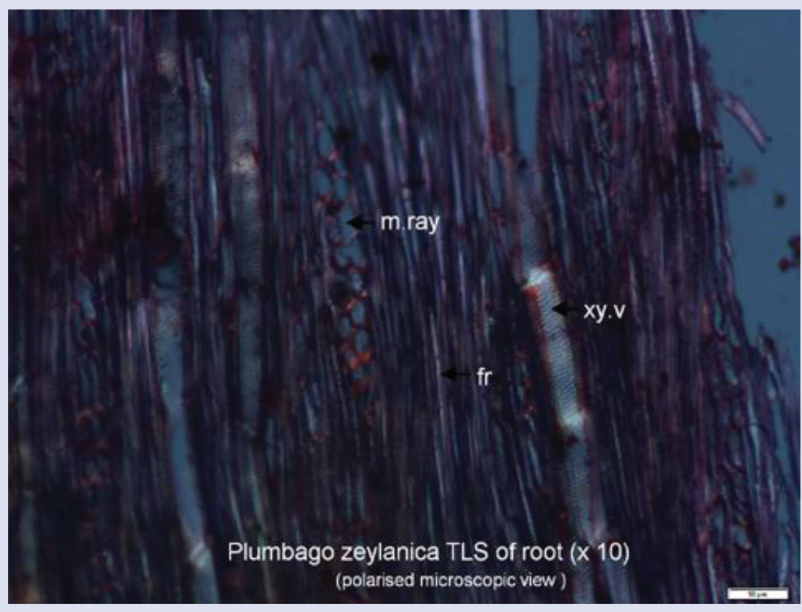

Figure 5b: P. zeylanica Linn. TLS of root: polarized view (x 10) 


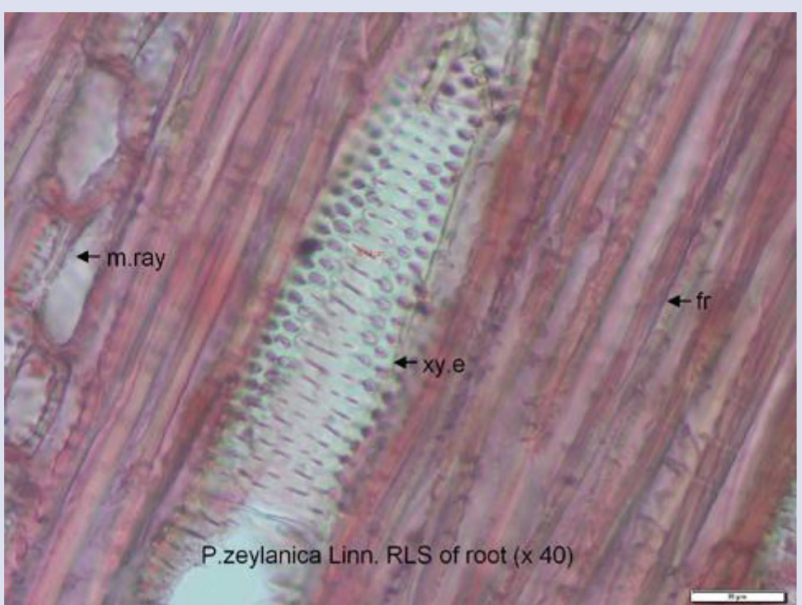

Figure 5c: P. zeylanica Linn. TLS of root $(x 40)$

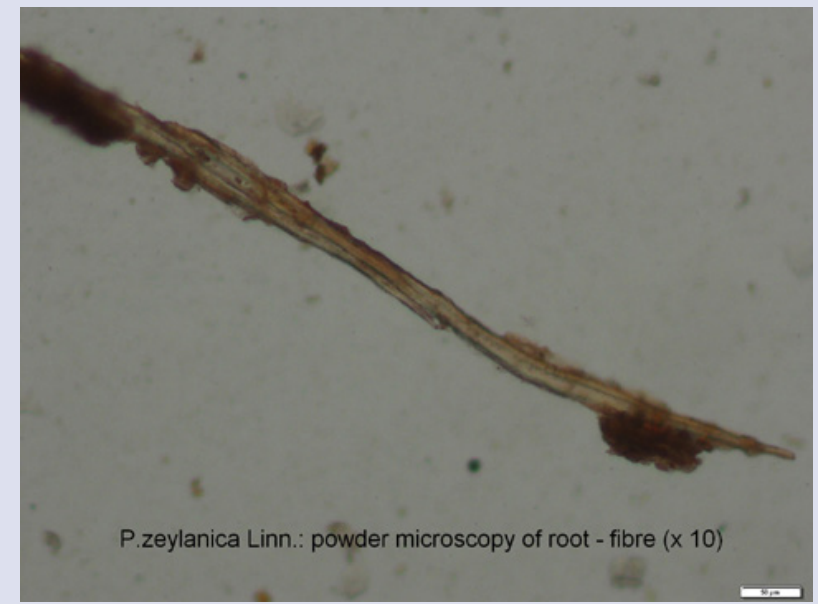

Figure 6: P. zeylanica Linn. Powder microscopy of root- libriform fibers $(x$ 10)

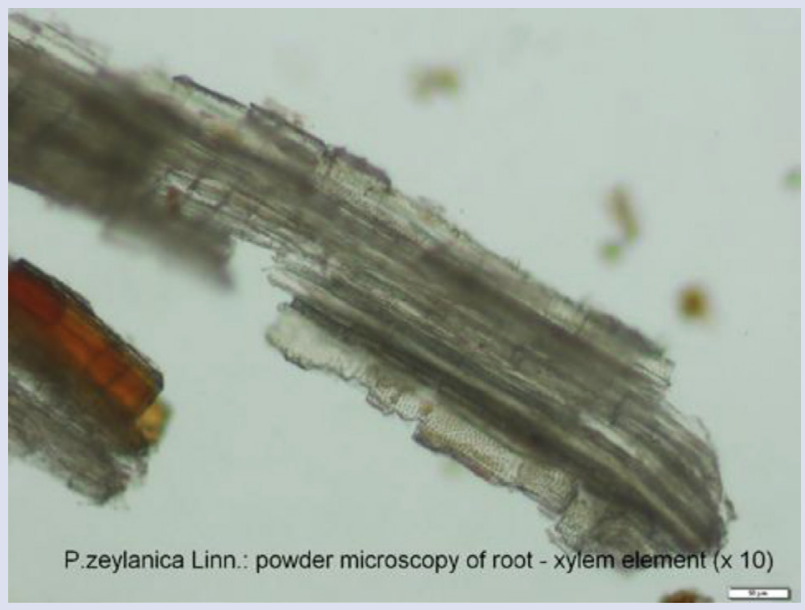

Figure 6a: P. zeylanica Linn. Powder microscopy of root- xylem elements ( $x$ 10)

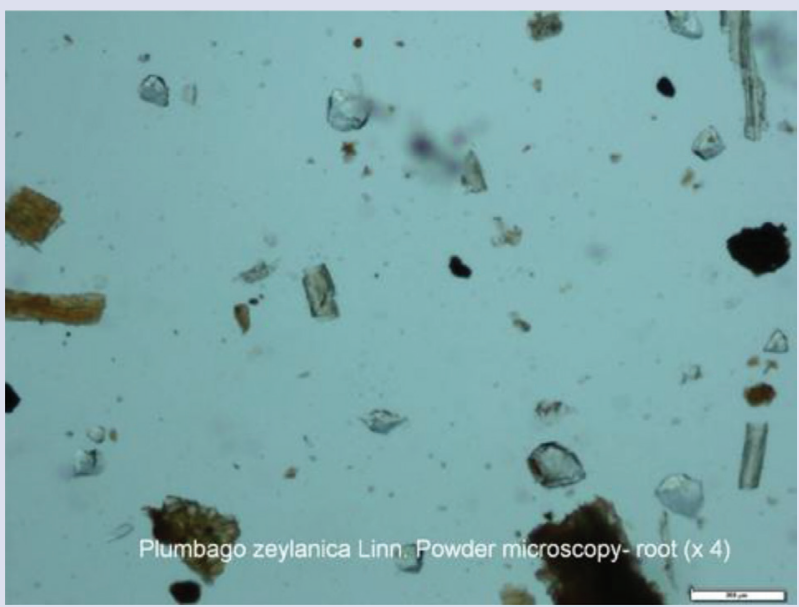

Figure 6b: P. zeylanica Linn. Powder microscopy of root- prismatic crystals (x 4)

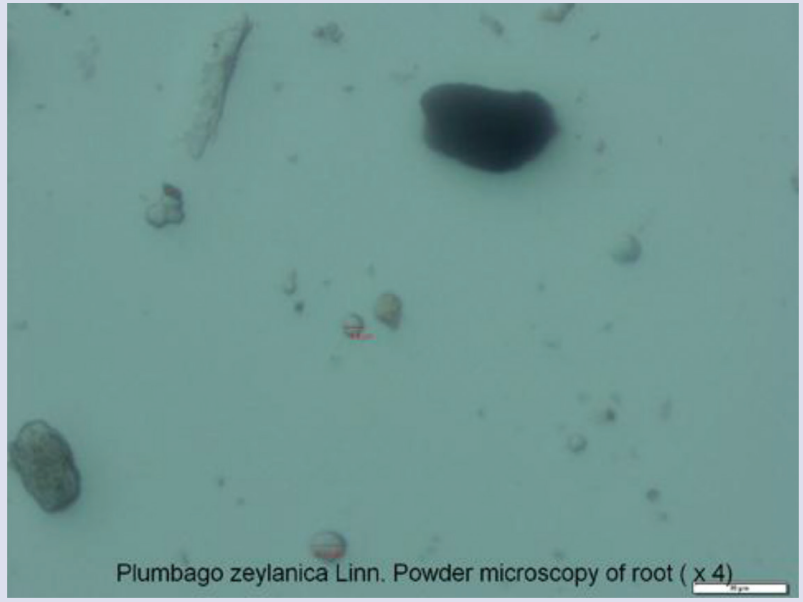

Figure 6c: P. zeylanica Linn. Powder microscopy of root- starch grains $(x 4)$

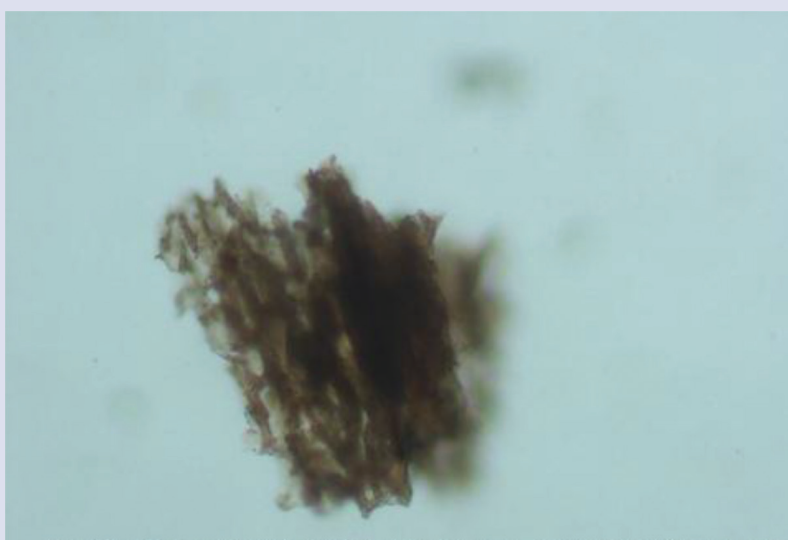

P.zeylanica Linn.: powder microscopy of root - parenchyma cells $(\times 10)$

(x)

Figure $6 \mathrm{~d}$ : P. zeylanica Linn. Powder microscopy of root- parenchyma $(x 10)$ 


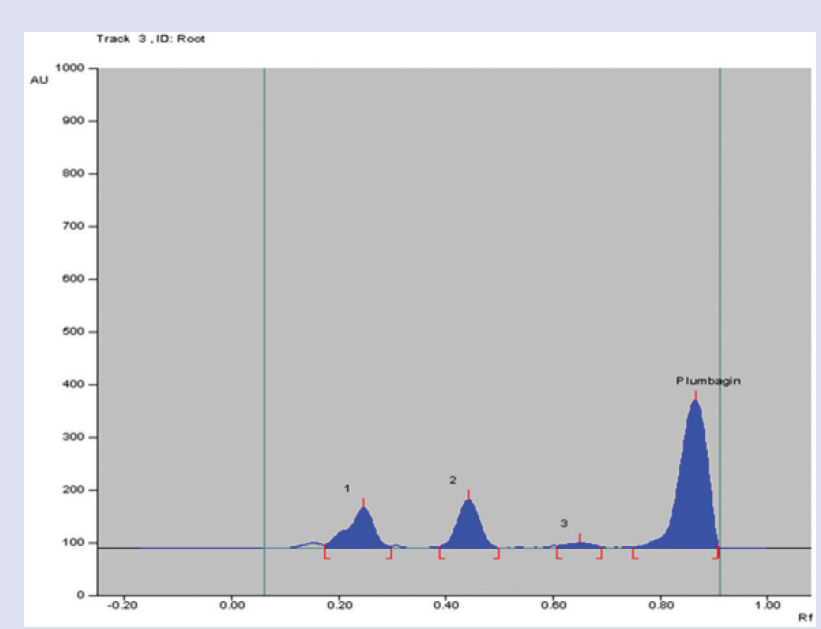

Figure 7: HPTLC chromatogram of methanol extract of $P$. zeylanica root

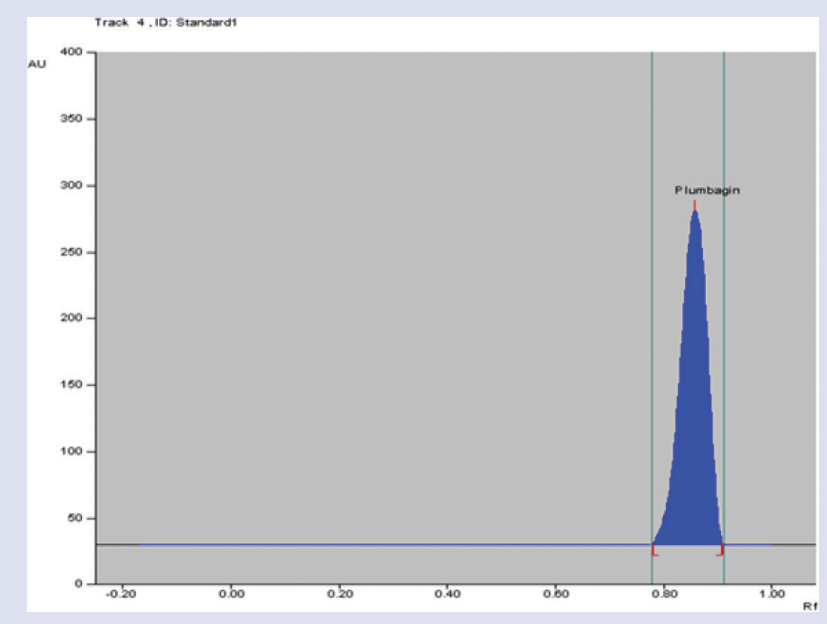

Figure 8: HPTLC chromatogram of plumbagin (1.05 $\mu \mathrm{l} / \mathrm{spot}$ ) with $R_{\mathrm{f}}=0.86$

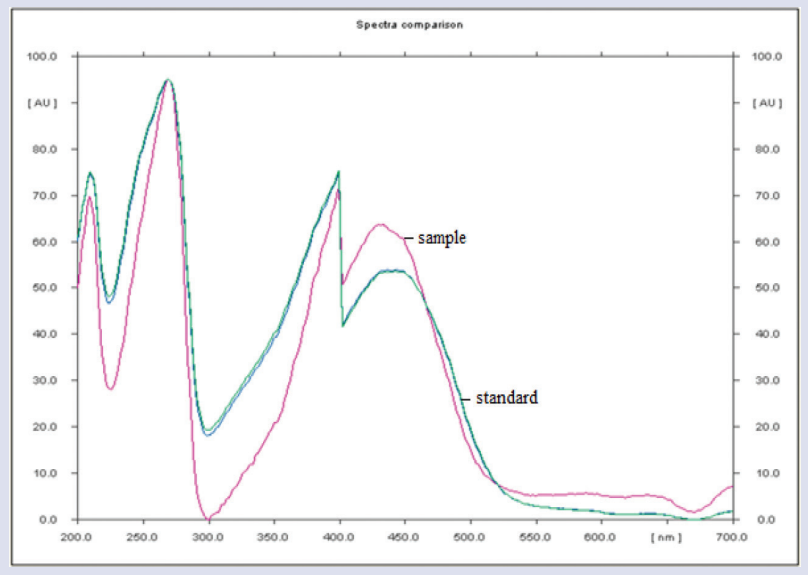

Figure 9: Overlay spectra $\left(\lambda_{\max } 270 \mathrm{~nm}\right)$ standard plumbagin (green colors) with methanol extract of root (pink color) of P.zeylanica Linn.

\section{Powder microscopy}

The dried roots of $P$. zeylanica were analyzed for powder characteristics. Root powder was yellowish brown in color and has no characteristic taste and odor. Microscopic examination of the root powder showed presence of pyramidal calcium oxalate crystals (Figure 6b); lignified libriform fibers with pointed ends (Figure 6a) simple and compound starch grains (Figure 6c). Fragments of parenchymatous tissues of the cortex (Figure 6d) and xylem elements (Figure 6a) were also observed.

\section{HPTLC Finger print}

The spotted samples of methanol extract of root of P. zeylanica and standard marker compound (plumbagin) containing on the silica gel plates were developed in the Twin trough chamber with the solvent system $\mathrm{n}$-hexane:ethyl acetate $8: 2(\mathrm{v} / \mathrm{v})$ to a distance of $8 \mathrm{~cm}$. All tracks in the plate were scanned at $254 \mathrm{~nm}$ and individual $\mathrm{R}_{\mathrm{f}}$ values and the resolved bands were recorded. The Chromatogram of the methanol extract of root had revealed four phyto-constituents (Figure 7). Data of peak area, peak height, $R_{f}$ value of each resolved band were recorded in track no.3 and the expressed pattern of chemical ingredient's distribution were also depicted in Figure 7. Out of these bands, one band $\left(R_{f}=0.87\right)$ generated had matched with the $\mathrm{R}_{\mathrm{f}}$ value $(0.86)$ of the marker compound (Figure 8 ) and the densitometric scanning had obtained the same $\lambda_{\max }$ $(270 \mathrm{~nm})$ as that shown by standard marker, Plumbagin.

\section{Quantitative Estimation}

Quantitative investigation of the marker compound (plumbagin) was carried out by densitometric reflection/absorption mode at $270 \mathrm{~nm}$ (Figure 8). Spectral matching by overlaying the absorption spectra of standard marker compound (9.00-11.00 $\mu \mathrm{g} / \mathrm{band})$ with the absorption spectrum of marker present in the extract of root sample (ie., plumbagin in the root) was confirmed the specificity of $\lambda_{\max }$ at $270 \mathrm{~nm}$ (Figure 9).

\section{Calibration curve}

When the concentrations of plumbagin $\left(\mathrm{C}_{11} \mathrm{H}_{8} \mathrm{O}_{3}\right)$ and their respective peak areas were subjected to regression analysis by polynomial method, calibration curve was found to be linear in the concentration range of 2.00 to $10.00 \mu \mathrm{g} / \mathrm{b}$ and with the calibration equation $\mathrm{Y}=178.8+91.61^{\star} \mathrm{X}$ $+-4.825^{\star} \mathrm{X} 2$ and regression coefficient, $\mathrm{r}=0.99735$ and $\mathrm{sdv}=3.02 \%$. Calibration graph showing the acceptable correlation $(r=0.997)$ between the $\mathrm{y}$ and $\mathrm{x}$ values had revealed a good linearity response for the method developed. The calibration data depicted in Table 1 had revealed that 5 $\mu \mathrm{L}$ of methanol extract of leaves contained $1.326 \mu \mathrm{g}$ of plumbagin and the content of marker constituent (plumbagin) present in dried root sample of P.zeylanica Linn (a Kerala habitant) was estimated as $0.1768 \%$. The finding of the present study in consonant with the other reported estimates $^{38-41}$ for the plumbign from the root samples of P.zeylanica Linn.

\section{Sensitivity of the HPTLC method}

The sensitivity of an instrument in an analytical procedure is a measure of its ability to discriminate between small differences in analyte concentration. According to Srivastava ${ }^{42}$ a signal-to-noise ratio $(\mathrm{S} / \mathrm{N})$ of 3.3 and 10 were generally be considered as limits of detection (LOD) and limits of quantitation (LOQ) respectively for HPTLC. The LOD and LOQ values of plumbagin calculated from the calibration regression equation were found to be $98.89 \mathrm{ng}$ and $329.66 \mathrm{ng}$ respectively. This suggests that the developed HPTLC method exhibits a good sensitivity for the quantitation of plumbagin. The developed active constituent based on HPTLC method has the advantage of simple, specific and easy identification of plumbagin in the root samples and could be applied for the regulatory perspective as routine quality analysis for the Plumbago species in the polyherbal formulation/finished products. 
Table 1: Calibration data of plumbagin at $270 \mathrm{~nm}$ by HPTLC

\begin{tabular}{|c|c|c|c|c|c|c|c|c|}
\hline Track & Vial & $R_{f}$ & $\begin{array}{l}\text { Amount } \\
\text { Fraction }\end{array}$ & Height & (X calc) & Area & (X calc) & Remark \\
\hline 4 & 4 & 0.86 & $1.050 \mu \mathrm{g}$ & 263.04 & & 9741.38 & & Std \\
\hline 5 & 4 & 0.86 & $3.150 \mu \mathrm{g}$ & 435.87 & & 17259.88 & & Std \\
\hline 6 & 4 & 0.86 & $5.250 \mu \mathrm{g}$ & 517.31 & & 21626.18 & & Std \\
\hline 7 & 4 & 0.86 & $7.300 \mu \mathrm{g}$ & 587.69 & & 25662.02 & & Std \\
\hline 8 & 4 & 0.85 & $9.450 \mu \mathrm{g}$ & 617.11 & & 27783.92 & & Std \\
\hline 3 & 3 & 0.87 & & 291.81 & $1.326 \mu \mathrm{g}$ & 10514.46 & $1.213 \mu \mathrm{g}$ & Sample root \\
\hline
\end{tabular}

\section{CONCLUSION}

Men in health profession and consumers alike are justifiably apprehensive about the quality of herbal medicine, batch to batch inconsistency and inefficacious marked products. Though the herb contains many phyto-constituents, standardization protocols for herbal medicine reliably lays in the development of finger print profiles. Delineation of anatomical markers and chemical profile of therapeutically important marker (s) with quantification of principle active component would appear to serve the only sensible ways towards establishing quality control parameters, which could reliably deliver appreciable health benefits. The results of the present study suggest that, the documented morphological descriptors, delineated anatomical markers and developed active constituent based on HPTLC finger print profile of the root of P.zeylanica Linn may supplement in the regulatory perspective of the routine quality control analysis of the crude drug and also for the Plumbagin in the formulation/ finished products.

\section{CONSENT}

Not applicable.

\section{CONFLICT OF INTEREST}

Author has declared that no conflict of interest exists

\section{ABBREVAITIONS USED}

CK:Cork; CO:Cortex; CRL, CRY: Crystal; FR: Fiber; PH: Phloem; M.RAY: Medullary ray; SS: Secretary substance; SCL:Sclereids; STR:Starch grain; S.XY:Secondary xylem; XY:Xylem

\section{REFERENCES}

1. Hook I, Mills C, Sheridan H. Bioactive naphthoquinones from higher plants. Studies in Natural Products Chemistry. Netherlands: Elsevier. 2014:119-60.

2. Dulong d'Astafort, M., J. Pharm. Sci. Accessoires.1828;14:441.

3. Durand R, Zenk MH. Biosynthesis of plumbagin (5-hydroxy-2-methyl-1, 4-naphthoquinone) via the acetate pathway in higher plants. Tetrahedron Letters. 1971;12(32):3009-12.

4. Durand $\mathrm{R}$, Zenk MH. The homogentisate ring-cleavage pathway in the biosynthesis of acetate-derived naphthoquinones of the droseraceae. Phytochemistry. 1974;13(8):1483-92.

5. Nazeem S, Azmi AS, Hanif S, Ahmad A, Mohammad RM. et al. Plumbagin induces cell death through a copper-redox cycle mechanism in human cancer cells. Mutagenesis. 2009;24(5):413-8. DOI: 10.1093/mutage/gep023

6. Srinivas P, Gopinath G, Banerji A, Dinakar A, Srinivas G. Plumbagin induces reactive oxygen species, which mediate apotopsis in human cervical cancer cells. Mol Carcinog. 2004;40(4):201-11. DOI: 10.1002/mc.20031

7. Kuo PL, Hsu YL, Cho CY. Plumbagin induces G2-M arrest and autophagy by inhibiting the AKT/mammalian target of rapamycin pathway in breast cancer cells. Molecular Cancer Therapeutics.2006;5(12):3209-21.DOI:10.1158/15357163.MCT-06-0478

8. Lai L, Liu J, Zhai D, Lin Q, He L, Dong Y. et al. Plumbagin inhibits tumor angiogenesis and tumor growth through VEGFR2-mediated Ras signaling pathway. Br J Pharmacol. 2012;165:1084-096.DOI: 10.1111/j.1476-5381.2011.01532.x.
9. Sivakumar KC, Nair RS, Srinivas G, Banerji A, Somasundaram V. Structure activity relationship of plumbagin in BRCA1 related cancer cells. Molecular carcinogenesis 2013;52(5):392-403.DOI: 10.1002/mc.21877

10. Sinha S, Pal K, Elkhanany A, Dutta S, Cao Y, Mondal G, et al. Plumbagin inhibits tumorigenesis and angiogenesis of ovarian cancer cells in vivo. Int J.2013;132(5):1201-12. DOI:10.1002/ijc.27724

11. Khaw AK, Sameni S, Venkatesan S, Kalthur G, Hande MP. Plumbagin alters telomere dynamics, induces DNA damage and cell death in human brain tumour cells. Mutat Res Toxicol Environ Mutagen.2015;793:86-95. DOI: 10.1016/j.mrgentox.2015.06.004

12. Chen $\mathrm{CA}$, Chang HH, Kao CY, TsaiTH, Chen YJ. Plumbagin, isolated from Plumbago zeylanica, induces cell death through apotopsis in human pancreatic cance cells. Pancreatol.2009;9(6):797-809. DOI: 10.1159/000210028

13. Pan ST, Qin Y, Zhou ZW, He ZX, Zhang X, Yang T.et al. Plumbagin induces G2/M arrest, apoptosis, and autophagy via p38 MAPK- and PI3K/Akt/mTOR-mediated pathways in human tongue squamous cell carcinoma cells. Drug Res Devel Ther.2015;9:1601.DOI: 10.2147/DDDT.S76057

14. Kai-HongXua, Dao-PeiLua. Plumbagin induces ROS-mediated apoptosis in human promyelocytic leukemia cells in vivo. Leukemia Res.2010;34(5):658-65. DOI: 10.1016/j. leukres.2009.08.017

15. Prasad VS, Devi PU, Rao BS, Kamath R. Radiosensitizing effect of plumbagin on mouse melanoma cells grown in vitro. Indian J Exp Biol.1996;34(9):857-58. PMID: 9014520

16. Nair S, Nair RR, Srinivas P, Srinivas G, Pillai MR. Radiosensitizing effects of plumbagin in cervical cancer cells is through modulation of apoptotic pathway. Mol Carcinog.2008;47(1):22-33. DOI:10.1002/mc.20359.

17. Sandur SK, Ichikawa H, Sethi G, Ahn KS, Aggarwal BB. Plumbagin (5-hydroxy2-methyl-1,4-naphthouinone), isolated from Plumbago zeylanica, inhibits ultraviolet radiation-induced development of squamose cell carcinomas. Carcinogenesis.2006;33(1):184-90.DOI: 10.1074/jbc.M601595200

18. The Plant List, Plumbago. Retrieved on 21 August, 2017. Available from: http:// www.theplantlist.org/1.1/browse/A/Plumbaginaceae/Plumbago/

19. Sivarajan W, Balachandran I. Ayurvedic Drugs and their Plant Sources. New Delhi: Oxford \& IBN Publishing Co; 2006.p.119-122.

20. Nadkarni KM. Indian materia medica. Bombay, India: Popular Book Depot;1954.p.990-91.

21. Chopra RN, Nayar SL, Chopra IC. Glossary of Indian Medicinal Plants (Including the Supplement) New Delhi: Council of Scientific and Industrial Research;1986.p.51-83

22. Jain AP, Hamrapurkar PD, Parate AN, Labana SM, Dnyanoba M, Madrewar DM. et al. Quantification and Isolation of Plumbagin (Plumbago zeylanica Linn.) by High-Performance Thin-Layer Chromatography. J Planar Chroma.2014;27(3):181-85.

23. Hsieh YJ, Lin LC, Tsai TH. Determination and identification of plumbagin from the roots of Plumbago zeylanica L.by Liquid Chromatography with Tandem Mass Spectrometry. J Chroma A. 2005;1083(1):141-45. DOI:10.1016/J.chroma.2005.06.030.

24. Bhattacharya A, Jindal B, Singh P, Datta A, Panda D. Plumbagin inhibits cytokinesis in Bacillus subtilis by inhibiting FtsZ assembly-a mechanistic study of its antibacterial activity. FEBS J.2013;280(18):4585-845

25. Nair SV, Baranwal G, Chatterjee M, Sachu A, Vasudevan AK, Bose C, et al. Antimicrobial activity of plumbagin, a naturally occurring naphthoquinone from Plumbago rosea, against Staphylococcus aureus and Candida albicans. Int J Med Microbiol.2016; 306(4):237-48. DOI: 10.1016/j.ijmm.2016.05.004

26. Bothiraja C, Joshi PP, Pawar AP. Rapid method for isolation of plumbagin, an alternative medicine from roots of Plumbago zeylanica. European J Integ Med 2011;3(1):39-42. https://doi.org/10.1016/j.eujim.2011.02.008

27. Ahmad A, Banerjee S, Wang Z, Kong D, Sarkar FH. Plumbagin-induced apoptosis of human breast cancer cells is mediated by inactivation of NF-kappaB and Bcl-2. J Cell Biochem. 2008;105(6):1461-71.DOI: 10.1002/jcb.21966

28. Sameni S, Hande MP. Plumbagin triggers DNA damage response, telomere dysfunction and genome instability of human breast cancer cells. Biomed Phar macotherapy.2016; 82:256-68. https://doi.org/10.1016/j.biopha.2016.05.007 
29. Itoigawa M, Takeya K, Furukawa H. Cardiotonic action of plumbagin on guineapig papillary muscle. Planta Med.1991;57(4):317-19. DOI: 10.1055/s-2006960106

30. Luo Y, Mughal MR, Ouyang TG, Jiang H, Luo W, Yu QS, et al. Plumbagin promotes the generation of astrocytes from rat spinal cord neural progenitors via activation of the transcription factor STAT3. J Neurochem.2010;115(6):1337-49. DOI:10.1111/j.1471-4159.2010.06780.x.

31. Iyenger MA, Pendse GS. Pharmacognosy of the root of Plumbago zeylanica L. Ind J Pharm. 1962;24:290-1.

32. Aiyer, NK, Kolmmal M. Plumbago zeylanica Linn. In Pharmacognosy of Ayurvedic Drugs (Kerala). Vol. 1 series 4, Trivendrum: Department of Pharmacognosy, University of Kerala; 1960.p.34-45.

33. Gupta AK, Tandon N, Sharma M. Plumbago zeylanica Linn. In Quality Standards of Indian Medicinal Plants. Vol.7. New Delhi: Published by Indian Council of Medical Research; 2008. p.218-26.

34. Metcalfe CR, Chalk L. Anatomy of the Dicotyledons: Wood Structure and Conclusion of the General Introduction. 2nd ed. Vol 2.Great Britain: The Clarendon,Oxford; 1985

35. Sudhakaran, MV. Pharmacognostic and HPTLC Fingerprint Profile of the Root of Aristolocia indica Linn and Quantification of the Marker Compound. European Med Plants. 2014;4(9):1113-24. www.sciencedomain.org
36. Carlquistt S, Boggs CJ. Wood anatomy of Plumbaginaceae. Bulletin of the Torrey Botanical Club.1996;123(2):135-47.

37. Carlquist S, Hoekmann DA. Ecological wood anatomy of the woody southern California flora.IAWA Bull.1985;6(4):319-347.DOI: 10.1163/22941932-90000960

38. Charlsdoni Al, Vidyalakshmi KS, Vasanthi HR Rajamanickam GV.HPTLC method for quantification of plumbagin in three Plumbago species. Res. J Phytochem.2007:1(1):46-51. http://scialert. net/archivedetails. php?issn=18193471\&issueno $=4$

39. Ariyanathan S, Saraswathy A, Rajamanickam GV. Quality Control Standards for the Roots of Three Plumbago Species. Ind J Pharm Sci. 2010:72(1):86-91. DOI:10.4103/0250-474X.62254

40. Rakhshi I, Pawar R, Singh K. Development of HPTLC method for the deter mination of plumbagin in chitrak haritak - an Ayurvedic formulation. Asian $J$ Phytomed Clin Res.2015;3(1):24-31. http://www.ajpcrjournal.com/archives.php

41. Pawar RK, Shivani S, Singh KC, Rajee SK.HPTLC method for the determination of Plumbagin from Plumbago zeylanica Linn.(root). Int. J Pharm Sci.2(4):219-23.

42. Srivastava MM. High performance thin layer chromatography. MM Srivastava,ed. London:Springer-Verlag, Berlin Heidelberg; 2011

\section{GRAPHICAL ABSTRACT}

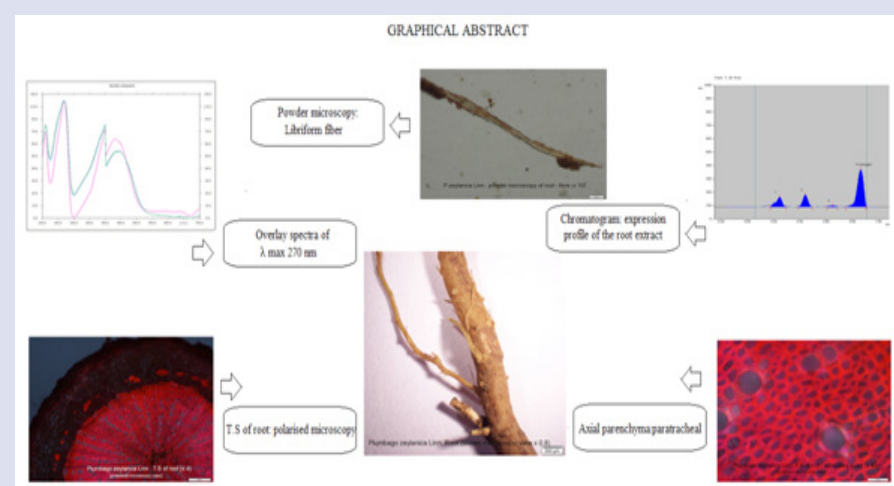

ABOUT AUTHORS

\section{SUMMARY}

- Plumbagin is the major active principle of Plumbago species. It is a powerful irritant and redox cycling compound. Plumbagozeylanica Linn.is espoused as source plant for the Ayurveda drug, Chitraka. It is used for the treatment in rheumatic pain, diarrhea and skin diseases and as an appetite stimulant, vesicantand contraceptive agent.

- Distinct band or patch of sclreids at the pericyclic region of the phloem of the root, wood with non-storied cambium, paratracheal axial parenchyma, chains of vessels in radial multiplies of three to six, wood plugged with tylosis and low mesomorphy ratio values for wood were the anatomical features characteristics of the taxon.

- Densitometric scanning of plambaginhad shown the characteristic $\lambda_{\max }$ at 270 $\mathrm{nm}$ by HPTLC method. The calibration graph plotted was found to be linear with the polynomial calibration equation $Y=178.8+91.61 * X+-4.825 * X 2$ and the percentage of plumbagin present in the shade-dried root of P. zeylanicala Kerala habitant)was estimated to be $0.179 \mathrm{w} / \mathrm{w}$.

- The anatomical markers, quantitative microscopic characteristics of the root, and developed HPTLC method could be effectively used for the regulatory perspectives of the quality assessment.

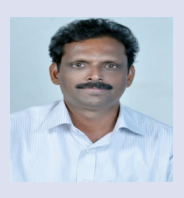

Madathilparambil Vasu Sudhakaran (M.V.Sudhakaran): Has received the Ph.D Degree of the University of Kerala. Currently he is positioned as Associate Professor, UGC-Academic Staff College of the University of Calicut. He is a research guide in Botany under the faculty of Science. His research interests include genetic diversity analysis, genetic effects of inbreeding, and the pharmacognostical and phytochemical aspects of medicinal plants.

Cite this article: Sudhakaran M.V. Histo-Chromatographic Finger Printing Profiles of the Root of Plumbago zeylanica Linn and Quantification of Marker Compound, Plumbagin. Pharmacog J. 2017;9(6)Suppl:s77-s86. 